\title{
Bladder Cancer Clinical TNM Finding v7
}

National Cancer Institute

\section{Source}

National Cancer Institute. Bladder Cancer Clinical TNM Finding v7. NCI Thesaurus. Code C89362.

A clinical finding about one or more characteristics of bladder cancer, following the rules of the TNM AJCC V7 classification system. Primary tumor assessment includes bimanual examination under anesthesia before and after endoscopic surgery (biopsy or transurethral resection) and histologic verification of the presence or absence of tumor when indicated. Appropriate imaging techniques for extravesical extension of the primary tumor and lymph node evaluation should be incorporated into clinical staging. (from AJCC 7th Ed.) 